Contents list available at IJRED website

Int. Journal of Renewable Energy Development (IJRED)

IJRED

Journal homepage: http://ejournal.undip.ac.id/index.php/ijred

\title{
Analyzing The Potential of Retrofitting Ultra-Low Heat Loss Triple Vacuum Glazed Windows to An Existing UK Solid Wall Dwelling
}

\author{
Saim Memon ${ }^{\mathrm{a}^{*}}$
}

aSchool of Engineering, Science \& Technology, North East Scotland College, Aberdeen, United Kingdom, AB123LE

\begin{abstract}
Heat loss through the windows of solid wall dwellings is one of the factors contributing to high energy consumption for space heating ensuing in preventable carbon emissions. This research forms a part of novel contribution in vacuum glazing science presenting the refurbishment technology of an experimentally achievable thermal performance of triple vacuum glazing to existing UK solid wall dwelling by investigating the space-heating load, solar energy gain and window to wall area ratios. Threedimensional dynamic thermal models, considering realistic heating and occupancy regimes, of an externally insulated solid wall dwelling with single glazed, double glazed air filled, double glazed argon gas filled, triple glazed air filled and triple vacuum glazed windows were developed. Predictions for the simulated dwelling when replacing single glazed windows with triple vacuum glazed windows indicate space-heating energy saving of $14.58 \%(871.1 \mathrm{kWh})$ for the winter months (Dec, Jan and Feb); predicted annual energy savings are $15.31 \%(1863.5 \mathrm{kWh})$. The predicted reduction in the solar energy gains for the triple vacuum glazing was 75.3 $\mathrm{kWh}$ in the winter months. The effects on solar energy gain are analysed and the potential to increase window-to-wall area ratios (WWR's) examined. For a simulated room with triple vacuum glazed windows increasing the WWR's from 5\% to 59\% led to a reduction in the predicted required space-heating; whilst for a room with single glazed, double air filled, double argon gas filled and triple air filled windows the predicted required space-heating increased with increasing WWR. It was shown that retrofitting existing solid wall dwelling with triple vacuum glazed windows could be a robust retrofit solution in improving building energy efficiency. This research also implicates a need of the cost-effective development of triple vacuum glazing at the manufacturing level, which would then be more beneficial to consumers in terms of energy and cost savings.
\end{abstract}

Keywords: solid wall dwelling, space-heating energy, solar gains, vacuum glazing

Article History: Received June 12, 2014; Received in revised form August 08, 2014; Accepted Sept 12, 2014 ; Available online

How to Cite This Article: Memon, S. (2014) Analysing the potential of retrofitting ultra-low heat loss triple vacuum glazed windows to an existing UK solid wall dwelling. Int. Journal of Renewable Energy Development, 3(3), 161-174.

http://dx.doi.org/10.14710/ijred.3.3.161-174

\section{Introduction}

Much of the UK housing stock built in the 19th and early 20th century has solid walls and is considered as hard-to-treat with regard to the heat loss through the fabric (Jelle et al. 2012). There are approximately 25 million dwellings in the current UK domestic stock, some 8.1 million (34\%) can be considered to be of solid wall construction and are responsible for about 50\% (Boardman et al. 2005) of total UK domestic sector carbon emissions of which space and water heating are the major contributors (Banfill et al. 2011; Loveday et al. 2011). A number of recent projects have proposed different solutions for the refurbishment of solid wall dwellings such as the study conducted by the Energy Saving Trust (2006) and the Tarbase project (Technology for carbon reduction in existing buildings) (Peacock et al. 2007) have investigated the refurbishment of UK solid-walled houses by analysing the potential $\mathrm{CO} 2$ emission reductions for a range of building variants (Jenkins 2008; Jenkins 2010). The energy saving measures and behaviours both by modelling and actual energy use, in eight local exemplars, in the West Bridgford (Nottingham) area were investigated in the HOBBs (Homes Behaving Badly) reports (Holt \& Schalom 2012). The BRE's

*Corresponding Author: Tel: +44-7735518528

Email: s.memon@nescol.ac.uk 
Victorian terrace retrofit project (Birch 2010) and a project for retrofitting of a conservation terrace area (Moorhouse \& Littlewood 2012) investigated a number of different retrofitting measures designed to improve the fabric and window performance. In all these projects double glazed air filled, triple glazed air filled and hybrid glazed windows with sputtered low emittance coatings were suggested as possible retrofit solutions for the window element of the envelope. Such windows have the potential to reduce the thermal transmittance value down to approximately $1.8 \mathrm{Wm}^{-2} \mathrm{~K}^{-1}$. The project CALEBRE (Consumer Appealing Low Energy Technologies for Building Retrofitting) (Vadodaria et al. 2010) investigated a number of advanced retrofit solutions including the development of ultra-low heat loss and cost-effective triple vacuum glazing. This research work is part of CALEBRE project and the continuing contribution to the vacuum glazing science providing a refurbishment technology of triple vacuum glazing for domestic energy efficiency. In this paper an experimentally achievable centre-of-pane thermal transmittance of triple vacuum glazing of 0.33 $\mathrm{Wm}^{-2} \mathrm{~K}^{-1}$ was used in three dimensional dynamic thermal models. Details of the novel sample fabrication, thermal performance measurements are reported elsewhere (Memon, 2013). The achievable thermal performance of triple vacuum glazed windows has been compared to a range of conventional window types; single, double glazed air filled, double glazed argon gas filled and triple glazed air filled windows.

The building design and its location play an important role with regard to the daylight, natural ventilation, solar gains, space-heating and electric lighting requirement. The interior space of a building within a certain distance from an external building envelope having windows has the advantages of daylight, the option of natural ventilation and useful solar gains in the winter months but also the disadvantages of high heat loss through the window and possibly excessive solar gains in spring, summer and autumn. An interior space sufficiently far away from the external envelope may require mechanical ventilation and electric lighting but will not suffer from undesirable excess solar gains and fabric heat loss. To choose the optimum window-to-wall area ratio by balancing the different parameters of gains and losses are reported by Baker \& Steemers (1996). In this research the effect of changing the window-to-wall area ratio, from 5\% to $59 \%$, on the required space-heating and solar energy gains of triple vacuum glazed window were comparatively analysed with conventional glazed windows. Day lighting can sometimes bring conflicts with visual and thermal comfort requirements due to overcast sky conditions, orientation, and lacks consideration of required illuminance task values (Ochoa et al. 2012). The details of daylight metrics and energy savings are reported by Mardaljevic et al. (2009). The research presented in this paper has analysed the potential space-heating, solar energy gains, window-to-wall area ratios and space-heating energy and cost savings achievable by retrofitting triple vacuum glazing compared with conventional glazing systems to an external insulated solid wall detached house.

\section{Methodology}

A number of thermal modelling software packages were studied such as IES VE, ESP-r, Energy Plus, TRANSYS, IDA ICE. These are having certain characteristics and specific applications (Crawley et al. 2005). In this paper IES VE dynamic thermal simulation tool has been used mainly because; it allows modelling triple vacuum glazed windows, due to its narrow gap/vacuum space between the two glass sheets i.e. $0.13 \mathrm{~mm}$; enable detailed evaluation of building spaceheating energy use, shading and solar penetration, natural ventilation and infiltration linked to occupancy, heating and ventilation profiles with the use of realistic weather data files.

An externally insulated solid wall detached house was modelled using IES VE (Integrated Environmental Solutions Virtual Environment) dynamic thermal modelling software (IES 2012) to predict space heating energy requirements and solar energy gains for different glazing types and different window-to-wall area ratios. The window types included in the simulations were single, double glazed air filled, double glazed argon gas filled, triple glazed air filled and triple vacuum glazed windows. Predictions were made of the annual performance and that for the winter months (Dec, Jan and Feb). A more detailed analysis is presented for the winter months due to the maximum heating energy requirement occurring at this time for buildings in the UK.

In building design, careful consideration of solar gain is essential since solar gain can lead to large variations in heating and cooling loads over the year. The effect of changing window-to-wall area ratio was analysed because lower heat loss glazings allow an increase in window size for a given rate of heat loss, while also enabling an increase in both solar energy gain and natural day lighting. Details of the simulation approach adopted are summarised in the block diagram presented in Fig. 1. 


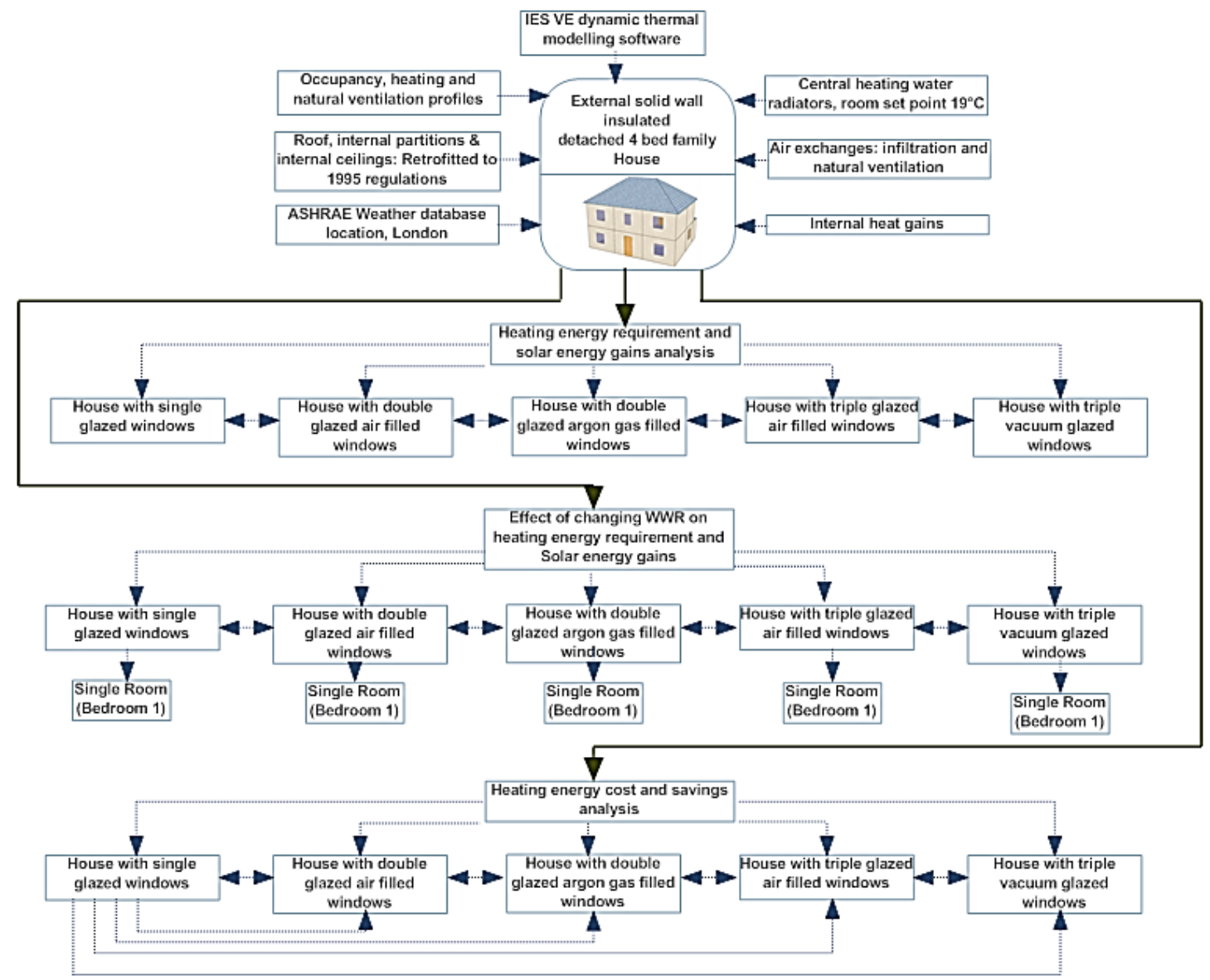

Fig. 1 An overview of the simulation approach employed for space heating and solar energy gain analysis of the externally insulated solid wall house retrofitted with different glazing systems.

\subsection{Simulation Building Design and Construction}

The building design is based on the likely construction of a 20th century solid wall dwelling. The detached solid wall house was considered to be located in the Heathrow area of London, UK. For the simulations the occupancy of the house was considered to be a family of three adults and one child. Schematic diagrams of the ground floor and first floor are presented in Figs. $2 \mathrm{a}$ and $2 \mathrm{~b}$ respectively.

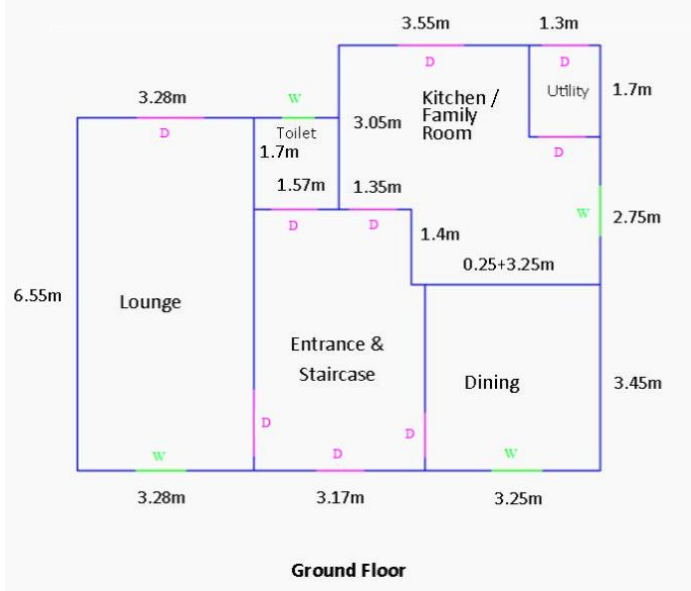

Fig. 2a Plan diagram of the ground floor

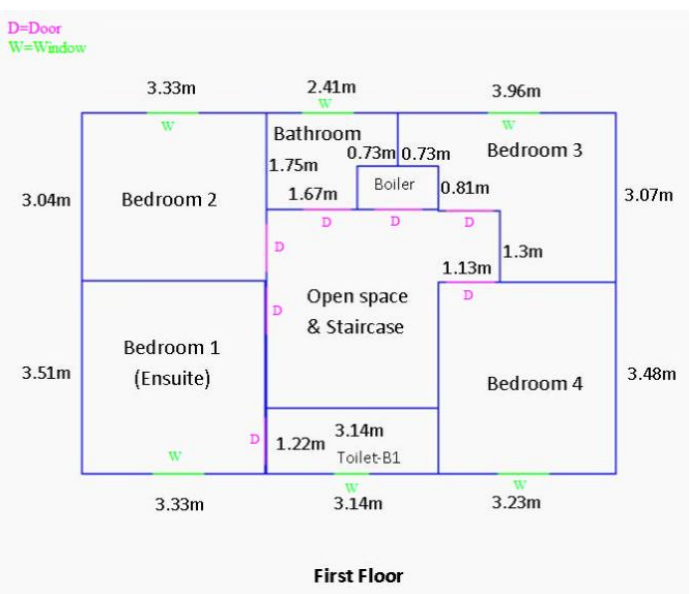

Fig. 2b Plan diagram of the first floor

Internal space partitions were created by dividing the house into separate zones corresponding to the dimensions of the lounge, dining room, kitchen/family room, bedrooms, utility room, boiler space, toilets and bathroom, details are presented in the Table 1. 
Citation: Memon, S. (2014), Analysing the potential of retrofitting ultra-low heat loss triple vacuum glazed windows to an existing UK solid wall dwelling. Int. Journal of Renewable Energy Development, 3(3),161-174, doi: 10.14710/ijred.3.3.161-174

$\mathrm{P}$ a g e 164

Table 1

Dimensions of the rooms in the modelled house

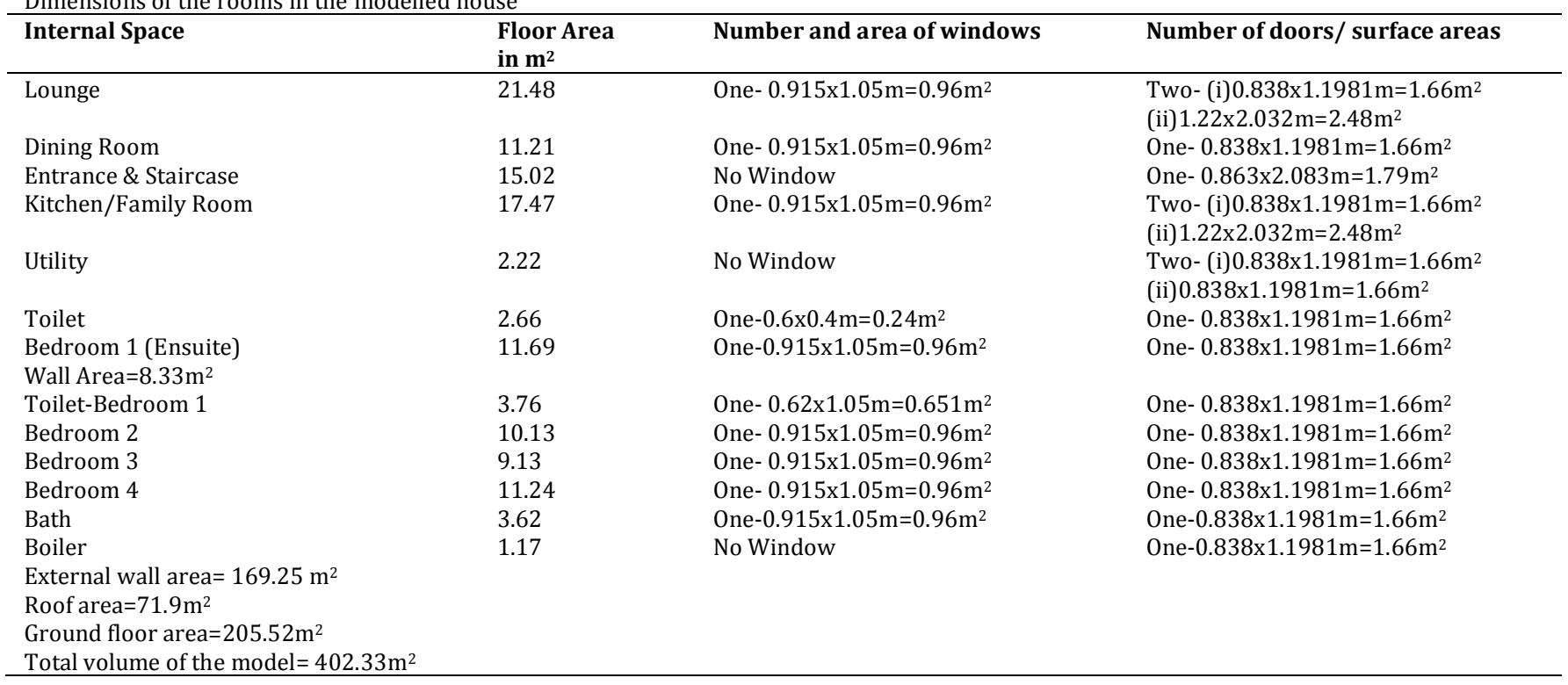

The internal space areas and numbers and size of windows and doors were estimated based on literature sources (Guillery et al. 2004; Lofthouse 2012; London Development Agency 2009). To determine the magnitude of heat loss through the windows only, all exterior doors were assumed to be of unglazed in construction. The front façade was assumed to be south facing. Fig. 2c illustrates the indicative external appearance of the modelled house. The total floor area of the modelled house was $133.62 \mathrm{~m}^{2}$ and the typical floor to ceiling height was $2.5 \mathrm{~m}$.

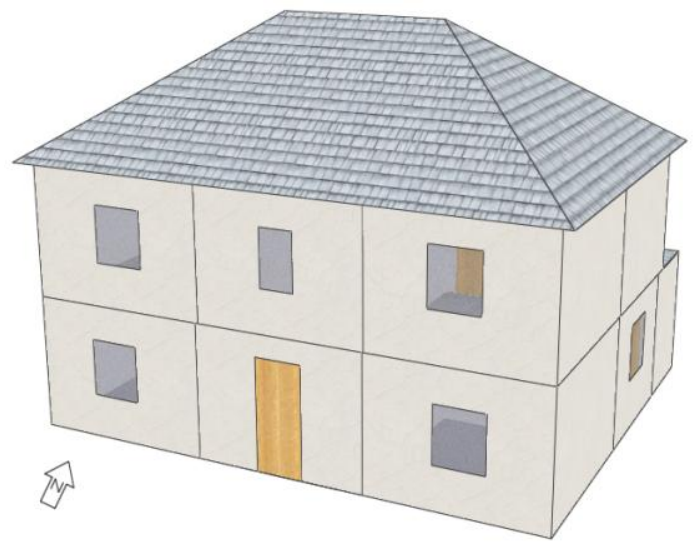

Fig. 2c A three dimensional textured image to give indicative external appearance of the modelled dwelling

The solid wall detached house modelled was constructed using brick thick bond wall (Smeaton 1867). A certain element of refurbishment was incorporated in the modelled building including loft insulation to 1995 building standards, details of the construction and the thermal properties for the modelled building are presented in Table 2. The elemental $U$ values of each element were determined using the method in the CIBSE Guide A (CIBSE 2006) and comply with the BS EN ISO 6946 standard (BS 2007a).

\subsection{Simulation Method}

A standard comfort temperature of between $17^{\circ} \mathrm{C}$ and $19^{\circ} \mathrm{C}$ for the winter season is recommended (CIBSE 2006). For the simulations, the inside heating set-point temperatures of all of the rooms were set to $19^{\circ} \mathrm{C}$. The ASHRAE design weather database v4.0 (IES-ASHRAE 2012) was used to provide outdoor weather conditions using the location of London/Heathrow and the example year, 1979-1980 weather data.

Within ApacheSim, the conduction, convection and radiation heat transfer processes for each element of the dwelling fabric were individually modelled and integrated with models of room heat gains and air exchanges (IES-ApacheSim 2012).

The analysis undertaken was transient, to account for the thermal mass of the building fabric elements (wall, roof, ceiling, and floor) a one-dimensional finite difference approach was used for the solution of the simple heat diffusion equation which can be represented in a spatially-discretised form (IESApacheSim 2012) as shown in Eq. 1.

$$
\frac{T_{n-1}-2 T_{n}+T_{n+1}}{\delta_{n}^{2}}=-\left(\frac{\rho c_{p}}{k}\right) \partial T / \partial t
$$


Table 2

The constructional details of the modelled solid wall dwelling with the calculated thermal transmittances (U) and thermal resistance (R) values

\begin{tabular}{|c|c|c|c|}
\hline \multicolumn{2}{|c|}{ Construction Details } & $\begin{array}{l}\text { U value } \\
\text { Wm-2 }^{-1}\end{array}$ & $\begin{array}{l}\text { R value } \\
\mathbf{m}^{2} \cdot \mathbf{K} / \mathbf{W}\end{array}$ \\
\hline $\begin{array}{l}\text { Externally } \\
\text { Insulated Solid } \\
\text { Wall }\end{array}$ & $\begin{array}{l}\text { External rendering with silicone finish }(0.01 \mathrm{~m} \text { thick }) \text {, phenolic foam }(0.03 \mathrm{~m} \text { thick }) \text {, Brickwork- } \\
\text { outer leaf }(0.225 \mathrm{~m} \text { thick }) \text { and gypsum plastering }(0.015 \mathrm{~m} \text { thick })\end{array}$ & 0.52 & 1.75 \\
\hline $\begin{array}{l}\text { Internal Ceiling } \\
\text { /Floors }\end{array}$ & $\begin{array}{l}\text { Wood planks } 0.022 \mathrm{~m} \text { thick, un-insulated cavity of } 0.24 \mathrm{~m} \text {, and gypsum/plaster board } 0.012 \mathrm{~m} \\
\text { thick }\end{array}$ & 1.51 & 0.43 \\
\hline Internal Partitions & $\begin{array}{l}\text { Single-leaf brick thick plastered on both sides }(0.013 \mathrm{~m} \text { gypsum plastering, } 0.115 \mathrm{~m} \text { thick } \\
\text { brickwork and } 0.013 \mathrm{~m} \text { gypsum plastering) }\end{array}$ & 1.97 & 0.25 \\
\hline Roofs & $\begin{array}{l}\text { Sloping roof including loft-insulated to } 1995 \text { building regulations }(0.02 \mathrm{~m} \text { thick clay tile, } 0.01 \mathrm{~m} \\
\text { cavity, } 0.005 \mathrm{~m} \text { roofing felt, } 0.8 \mathrm{~m} \text { cavity, } 0.15 \mathrm{~m} \text { glass-fibre quilt and } 0.013 \mathrm{~m} \text { gypsum plasterboard. }\end{array}$ & 0.23 & 4.15 \\
\hline $\begin{array}{l}\text { Ground } \\
\text { contact/Exposed } \\
\text { floors }\end{array}$ & $\begin{array}{l}\text { Un-insulated suspended timber floor }(0.75 \mathrm{~m} \text { thick London clay, } 0.25 \mathrm{~m} \text { thick brickwork, } 0.2 \mathrm{~m} \\
\text { cavity, } 0.025 \mathrm{~m} \text { thick chipboard and } 0.01 \mathrm{~m} \text { synthetic carpet) }\end{array}$ & 0.63 & 0.85 \\
\hline Doors & Solid hardwood door-normally hung (0.042m Oak-radial) & 2.56 & 0.22 \\
\hline
\end{tabular}

The thermo-physical properties such as the thermal conductivity $k\left(\mathrm{Wm}^{-2} \mathrm{~K}^{-1}\right)$, the density $\rho\left(\mathrm{kg} / \mathrm{m}^{3}\right)$ and the specific heat capacity $c_{p}\left(\mathrm{Jkg}^{-1} \mathrm{~K}^{-1}\right)$ of each element were assumed to be uniform within each layer. $T_{n}$ is the temperature $\left({ }^{\circ} \mathrm{C}\right)$ at node $\mathrm{n}$ and $\delta \mathrm{n}$ is the local node spacing $(\mathrm{m})$.

For determination of the solar radiation incident on the dwelling surfaces, the variation of direct solar radiation perpendicular to the plane and the diffuse solar radiation horizontal to the plane with solar altitude and azimuth angles were used with actual weather data for the year 1979-1980 and the location London/Heathrow (IES-ASHRAE 2012). Both shading and solar radiation incident on the glazing and transmitted to the interior of the house were modelled using the Suncast shading data analysis tool (IES 2012). For the building simulations a time step setting of 1 minute with a reporting interval of 60 minutes and a preconditioning period of 10 days were used in the apache thermal simulation calculations.

In the dynamic thermal model, two thermal transmittance values for windows were incorporated i.e. with the inclusion of the effects of the frame and the centre-of-pane $U$ value calculated using either CIBSE/EN-ISO standards. The modelled design details including the centre-of-pane $\mathrm{U}$ value for single, double glazed air filled, double glazed argon gas filled, triple glazed air filled and triple vacuum glazed windows are presented in Table 3.

Table 3

Glazed window design details

\begin{tabular}{|c|c|c|c|c|}
\hline Window type & Thickness & Type of coatings (Emissivity) & $\begin{array}{l}\text { Cavity Thermal } \\
\text { Resistance }\end{array}$ & $\begin{array}{l}\text { Centre-of- pane U values } \\
\mathrm{Wm}^{-2} \mathrm{~K}^{-1}\end{array}$ \\
\hline Single & $\begin{array}{l}4 \mathrm{~mm}= \\
1 \mathrm{x} 4 \mathrm{~mm} \text { (glass) }\end{array}$ & $\begin{array}{l}\text { No coating } \\
(0.89)\end{array}$ & - & 5.75 (EN-ISO) (CIBSE 2006) \\
\hline $\begin{array}{l}\text { Double glazed Air- } \\
\text { filled }\end{array}$ & $\begin{array}{l}20 \mathrm{~mm}= \\
2 \times 4 \mathrm{~mm} \text { (glass) } \\
1 \times 12 \mathrm{~mm} \text { (cavity) }\end{array}$ & Two Tin Oxide (0.15-0.18) & $0.173 \mathrm{~m}^{2} \mathrm{~K} / \mathrm{W}$ & 2.85 (EN-ISO) (CIBSE 2006) \\
\hline $\begin{array}{l}\text { Double glazed Argon } \\
\text { gas filled }\end{array}$ & $\begin{array}{l}20 \mathrm{~mm}= \\
2 \times 4 \mathrm{~mm} \text { (glass) } \\
1 \times 12 \mathrm{~mm} \text { (cavity) }\end{array}$ & Two Tin Oxide (0.15-0.18) & $0.196 \mathrm{~m}^{2} \mathrm{~K} / \mathrm{W}$ & 2.67 (EN-ISO) (CIBSE 2006; BS 1998) \\
\hline $\begin{array}{l}\text { Triple glazed Air- } \\
\text { filled }\end{array}$ & $\begin{array}{l}20 \mathrm{~mm}=36 \mathrm{~mm} \\
3 \times 4 \mathrm{~mm} \text { (glass)- } \\
2 \times 12 \mathrm{~mm} \text { (cavity) }\end{array}$ & Three Tin Oxide (0.15-0.18) & $0.173 \mathrm{~m}^{2} \mathrm{~K} / \mathrm{W}$ & 1.89 (EN-ISO) (CIBSE 2006) \\
\hline $\begin{array}{l}\text { Triple Vacuum } \\
\text { Glazed }\end{array}$ & $\begin{array}{l}12.26 \mathrm{~mm}= \\
3 \times 4 \mathrm{~mm} \text { (glass)- } \\
2 \times 0.13 \mathrm{~mm} \text { (cavity) }\end{array}$ & Three Tin Oxide (0.15-0.18) & $1.42 \mathrm{~m}^{2} \mathrm{~K} / \mathrm{W}$ & $0.33^{*}$ \\
\hline $\begin{array}{l}\text { Frame material }=\text { PVC } \\
\text { Visible light normal tr } \\
\text { G-value }=0.76 \\
\text { Inside and outside sur }\end{array}$ & $\begin{array}{l}\text { nsmittance is kept consta } \\
\text { ace emissivity }=0.9 / 0.9\end{array}$ & $t=0.74$ & & \\
\hline
\end{tabular}


A centre-of-pane thermal transmittance $\left(U_{g}\right)$ value for a single glazing was calculated using Eq. 2. For multiple glass layers, for example double glazed air filled, double glazed argon gas filled, triple glazed air filled, and triple vacuum glazing the $\mathrm{U}_{\mathrm{g}}$ value were calculated using Equ. 3.

$$
\begin{gathered}
\mathrm{U}_{\mathrm{g}}=\frac{1}{R_{s e}+\frac{d}{k}+R_{s i}} \\
\mathrm{U}_{\mathrm{g}}=\frac{1}{R_{s e}+\sum_{j} \frac{d_{j}}{k_{j}}+\Sigma_{j} R_{s, j}+R_{s i}}
\end{gathered}
$$

Where $k$ is thermal conductivity of the glass with a constant value $1.0 \mathrm{Wm}^{-1} \mathrm{~K}^{-1}$ (BS 1998) used, $d$ is the thickness of the glass pane i.e. $0.004 \mathrm{~m}$ which is common to all window types modelled and $R_{s, j}$ is the space thermal resistance, given in Table 3, of cavity/cavities (A cavity can be filled with air or argon or can be under vacuum). $R_{s e}$ and $R_{s i}$ are external and internal glass surface thermal resistances with a fixed value of 0.04 $\mathrm{m}^{2} \mathrm{KW}^{-1}$ and $0.13 \mathrm{~m}^{2} \mathrm{KW}^{-1}$ used, respectively (BS 2007a). The frame $U$ values $\left(U_{f}\right)$ are depending on the size of windows and calculated, accordingly, using Eq. 4.

$$
\mathrm{U}_{\mathrm{f}}=\frac{1}{R_{s i} \frac{A_{f, i}}{A_{f_{i} d \mathrm{i}}}+R_{f}+R_{s e} \frac{A_{f_{i} \varepsilon}}{A_{f_{i} d \theta}}}
$$

Where, $A_{f, i}$ is the internal projected frame area in $\mathrm{m}^{2}$ including sashes if present on a plane parallel to the glass surface (BS 2006). $A_{f, e}$ is the external projected frame area in $\mathrm{m}^{2} . A_{f}$ is the frame area of the larger of the two projected areas seen from both sides in $\mathrm{m}^{2} . A_{f, d i}$ is the internal frame area that includes sashes if present in contact with the internal air in $\mathrm{m}^{2}$. $A_{f, d e}$ is the external frame area in $\mathrm{m}^{2} . A_{w}$ is the window area in $\mathrm{m}^{2}$ which is equal to the addition of $A_{f}$ and $A_{g} . R_{f}$ is the thermal resistance of the frame section i.e. $0.33 \mathrm{~m}^{2} \mathrm{~K} / \mathrm{W}$ for a frame width of $0.09 \mathrm{~m}$ constructed from PVC.

The net window $U$-value $\left(U_{w}\right)$ was calculated from Equ. 5 by taking an average of the En-ISO centre-ofpane $\left(\mathrm{U}_{\mathrm{g}}\right)$ and frame $\mathrm{U}$-values $\left(\mathrm{U}_{\mathrm{f}}\right)$ weighted according to their percentage contribution to the area of the window (BS 2003).

$$
\mathrm{U}_{\mathrm{w}}=\mathrm{U}_{\mathrm{f}}\left(\frac{A_{f}}{A_{\mathrm{w}}}\right)+\mathrm{U}_{\mathrm{g}}\left(\frac{A_{g}}{A_{w}}\right)
$$

\subsubsection{Occupancy and Imposed Heating Regime}

The behaviour, habits and actions performed by the occupant in a domestic dwelling are influenced by cultural, social and physiological driving forces
(Papakostas \& Sotiropoulos 1997) and are likely to be different within each house. Increasing the number of occupants within a building could lead to an increase in energy use for space heating if heat is required to increase the temperature in an occupied zone to achieve thermal comfort temperatures, however a larger number of occupants in a building will also increase the casual internal heat gains that results from their activities, this will offset some of the space heating energy requirements. In the simulations a water based central heating radiator using LTHW (Low Temperature Hot Water) with a gas fired boiler supplying water at $60^{\circ} \mathrm{C}$ was selected. The occupancy profiles were created based on likely daily (Monday to Friday), weekend and holiday occupancies. These profiles were then used to generate a yearly occupancy profile. It was assumed that the house was occupied by four people from $6 \mathrm{pm}$ to $8 \mathrm{am}$, by one person from $8 \mathrm{am}$ to $3 \mathrm{pm}$ and by two people from $3 \mathrm{pm}$ to $6 \mathrm{pm}$ from Monday to Friday. During the weekend, the house was assumed to be occupied by four people from $6 \mathrm{pm}$ to $9 \mathrm{am}$ and during holiday periods the house was scheduled to be unoccupied. When the inside air temperature falls below $19^{\circ} \mathrm{C}$ the heating system in the simulation was turned on, this was incorporated in to the settings along with the occupancy profile.

\subsubsection{Natural Ventilation}

For these simulations, infiltration was considered to be the air exchange mechanism and was determined based on the occupancy profile. The air exchange rates used depend on the volume of the rooms, design of the walls and occupant activities. The CIBSE Guide A- Table 4.21 (CIBSE 2006) provides a peak empirical value for air infiltration into a room in a two storey dwelling, with an air permeability of $10 \mathrm{~m}^{3} \mathrm{~h}^{-1} \mathrm{~m}^{-2}$ based on Part $\mathrm{L}$ of the 2002 building regulations (IES-Part L2 2006) to be 0.75 ach and the minimum air infiltration rate recommended is 0.35 ach (Mudarri 2010), these values comply with the ASHRAE Standard 62 (ASHRAE 1989). For these simulations, the air infiltration rate was set to be 0.5 ach (BRE 2005) due to infiltration in dwellings with solid brick walls being higher than that of standard cavity walls. The infiltration changes due to the increasing length of the frame when increasing the window-to-wall area ratios and also the cold bridge influences were taken into account. Natural ventilation results due to windows being opened by building occupants (BS 2007b). The profiles used for natural ventilation were created based on the condition that if the inside air temperature exceeds $24^{\circ} \mathrm{C}$ and the building is occupied then the windows are open. A typical value of 5 ach was used when modelling natural ventilation due to windows being opened (CIBSE 2012; CIBSE 1997). 


\subsubsection{Internal Heat Gains}

Internal heat gains from people were included in all simulations. Typical rates of sensible heat gains and latent heat gains from people depend on the type of activities and occupancy (number of people and time) in the dwelling. Based on the data available from surveys of buildings (CIBSE 2006), the type of activity was assumed to be constant in the dwelling, i.e. seated, very light work. The rate of heat emission used 70W (sensible heat gain) and 45W (latent heat gains) was for a mix of males and females. A maximum of four people were included in the occupancy profile detailed previously in section 2.2.1.

Internal heat gain due to artificial lighting (fluorescent lighting) was included in the simulation with a separate profile/schedule created for lighting use based on occupancy. In the profile used, lighting was switched on from $6 \mathrm{pm}$ to $12 \mathrm{pm}$ from Monday to Friday and on weekends, during holidays there were no lighting loads as the house was scheduled to be unoccupied. The lighting simulated was based on compact fluorescent lighting. CIBSE Guide A (CIBSE 2006) states the lighting energy required for commercial and similar applications (e.g. offices, shops, schools) has a maximum of 300 lux with an average installed power density of $8 \mathrm{~W} / \mathrm{m}^{2}$. Due to the difference of activities and lighting use in domestic dwellings, a suggested maximum sensible heat gain from the lighting of $12 \mathrm{~W} / \mathrm{m}^{2}$ was used (Porritt et al. 2010) and was implemented via the lighting profile.

\section{Results and Discussions}

In the following sub-sections the space-heating and solar energy gains are analysed for the winter months for the externally insulated solid wall detached house with triple vacuum glazed windows, single, double glazed air filled, double glazed argon gas filled and triple glazed air filled glazed windows. The influence of changing WWR on the space-heating energy requirements and solar energy gains for the winter months is analysed. The achievable space heat energy savings and cost analysis for the winter and for a year are also presented. The predicted inside resultant air temperatures of the house are shown in Fig. 3.

\subsection{Heat load analysis for a day of high heat load}

The maximum heat load was predicted from the simulations to occur on the 29th of December. Fig. 4 shows that the heat supplied to the house with triple vacuum glazed windows is less than the heat supplied to the house with other types of glazed windows. On this peak day, it can be seen that switching the heating system off from 8 am to $6 \mathrm{pm}$ hours increased the spaceheating requirement range from $4.2-6 \mathrm{~kW}$ to $7.2-8.4$ $\mathrm{kW}$. It can be seen that from $6 \mathrm{pm}$ to $7 \mathrm{pm}$ the space heat requirement reduces to between $6.2 \mathrm{~kW}$ to $7.2 \mathrm{~kW}$, depending on the type of glazing system used. The simulation results show that on this day the minimum space heating requirement for the house with triple vacuum glazed windows. The predicted heat for a house with double glazed argon gas filled windows was slightly less than that for double glazed air filled windows, due to the small difference in the thermal transmittance values.

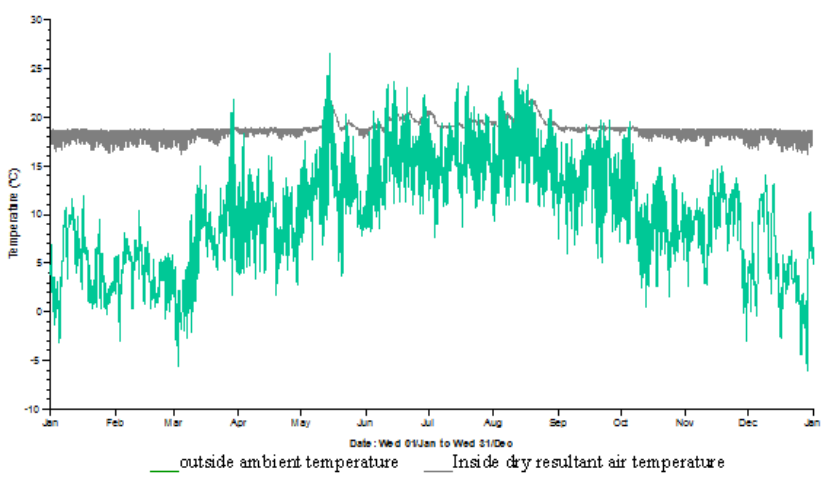

Fig. 3 Annual predicted inside dry resultant air temperature of the house and outside ambient temperature from the ASHRAE database temperature profile for London/Heathrow UK.

The heating system was turned off between 8am and $6 \mathrm{pm}$, during which time the inside air temperatures of the house with different glazing systems decreased down to $16^{\circ} \mathrm{C}$, as shown in Fig. 4. Due to this when the heating system is switched on, the maximum space heat load occur.

\subsection{Winter heating energy requirements}

The cumulative space heat energy savings resulting from replacing single glazed windows with triple vacuum glazed windows were predicted to be 297.7 kWh, $298.2 \mathrm{kWh}$ and $275.2 \mathrm{kWh}$ for the months of Dec, Jan and Feb for the simulated dwelling as illustrated in Figs. 5, 6 and 7. The total winter months heat load reductions were calculated to be $465.4 \mathrm{kWh}, 496.8 \mathrm{kWh}$, $605.6 \mathrm{kWh}$ and $869.7 \mathrm{kWh}$ for the house with double glazed air filled, double glazed argon filled, triple glazed air filled and triple vacuum glazed windows when compared to the house with single glazed windows. It can be seen that savings in total winter heat load of $264.1 \mathrm{kWh}$ can be achieved for the winter months for a house with triple vacuum glazed windows compared to a house with triple glazed air filled windows.

\subsection{Solar gain analysis for a day of high solar gains (14th February) during the winter months}

The maximum solar gains during the winter months were predicted to occur at $11 \mathrm{am}$ on the $14^{\text {th }}$ of February. Fig. 8 shows that the house with single glazed, double glazed air filled, double glazed argon filled, triple glazed air filled and triple vacuum glazed windows receives solar gains of $1.99 \mathrm{~kW}, 1.63 \mathrm{~kW}, 1.64 \mathrm{~kW}$, $1.38 \mathrm{~kW}$, and $1.42 \mathrm{~kW}$ respectively. 


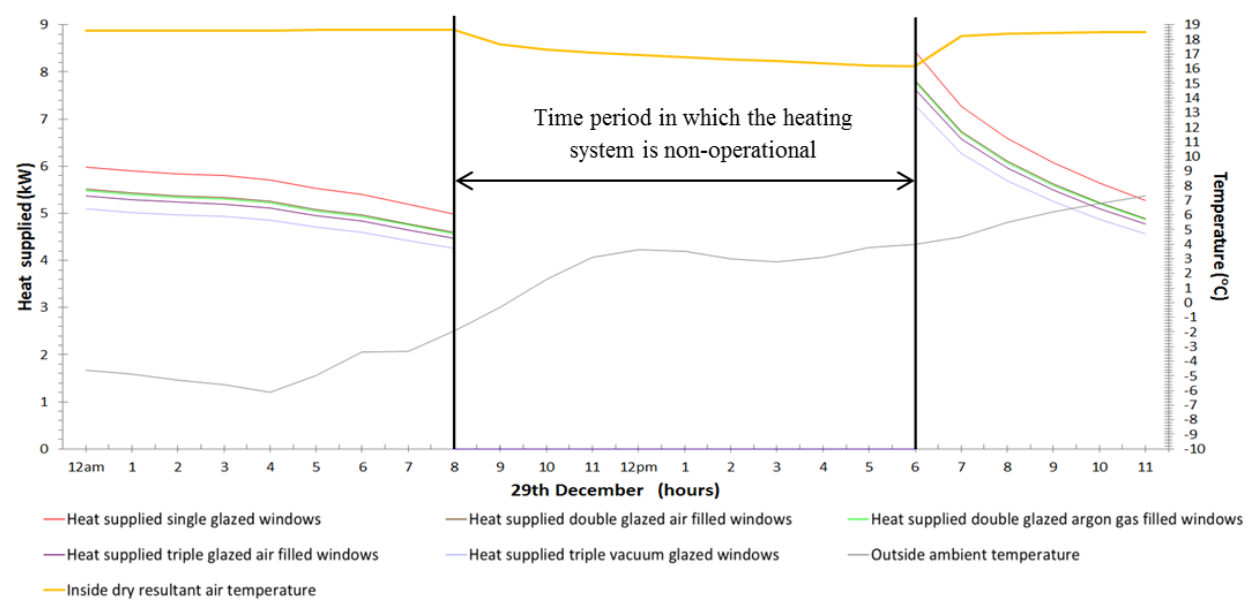

Fig. 4 Predicted indoor air temperature and heat supplied for a day of high heat load on the 29th of December during the winter months (Dec, Jan and Feb) for the modelled house with different window types.

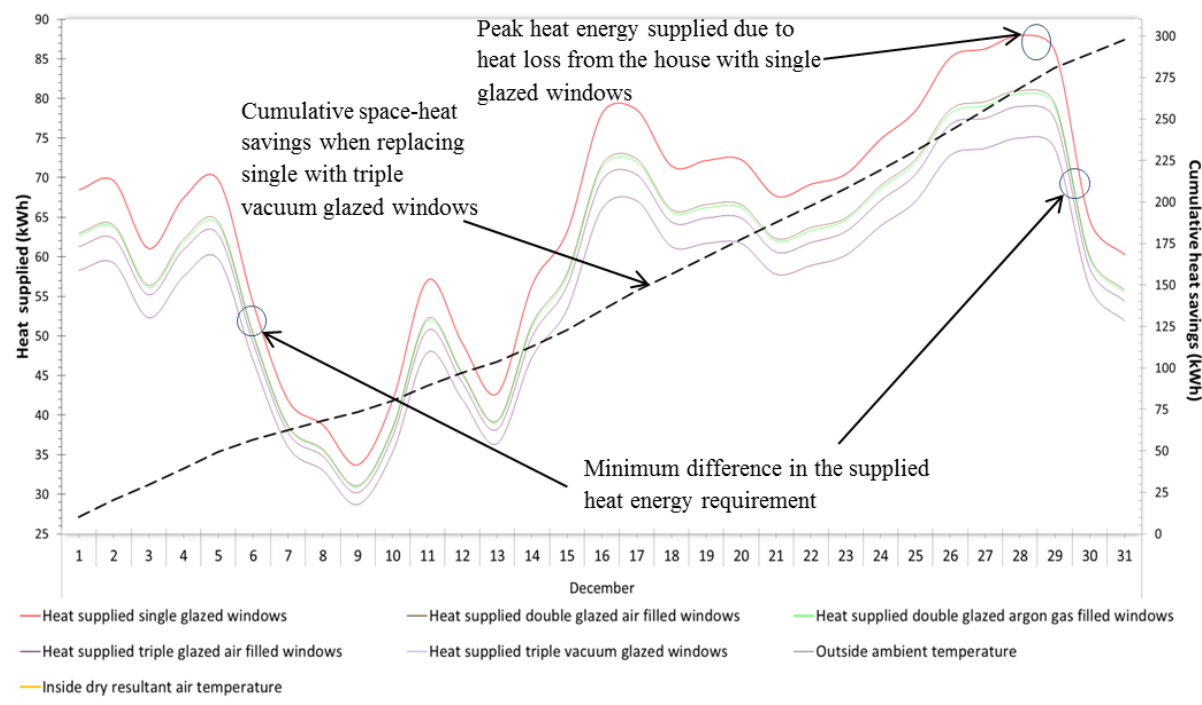

Fig. 5 Predicted heat load for the month of December for the house with single, double glazed air filled, double glazed argon gas filled, triple glazed air filled and triple vacuum glazed windows

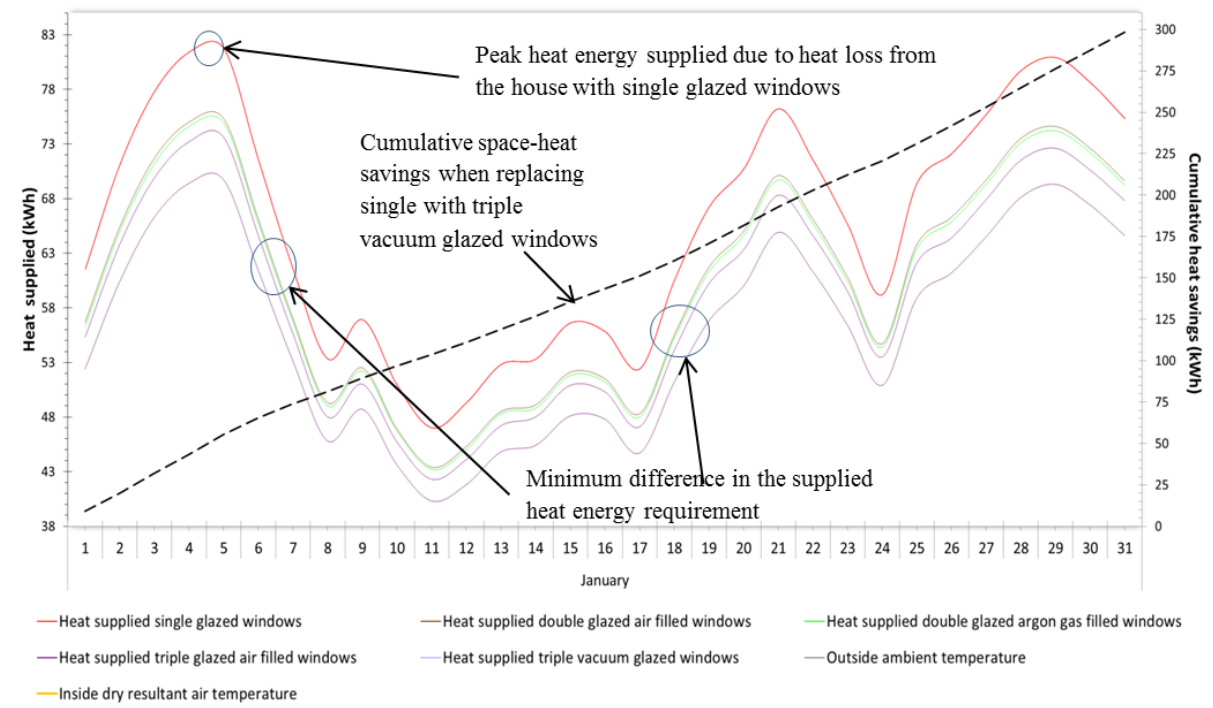

Fig. 6 Predicted heat load for the month of January for the house with single, double glazed air filled, double glazed argon gas filled, triple glazed air filled and triple vacuum glazed windows. 


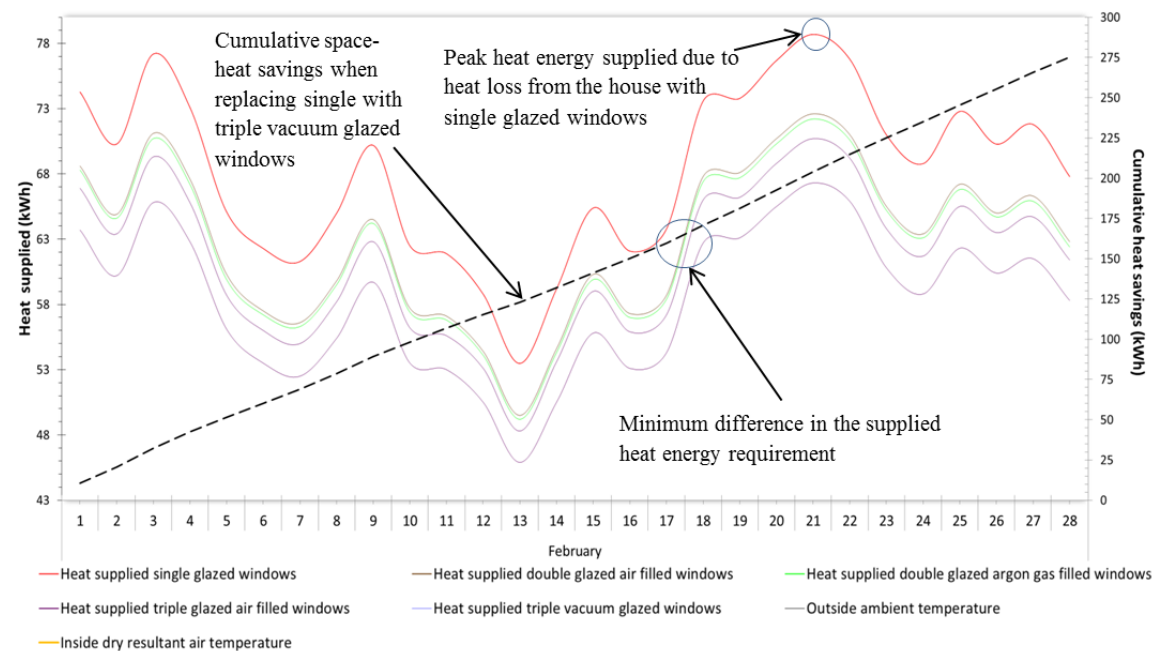

Fig. 7 Predicted heat load for the month of February for the house with single, double glazed air filled, double glazed argon gas filled, triple glazed air filled and triple vacuum glazed windows.

It can be seen that the house with triple vacuum glazed windows received $0.57 \mathrm{~kW}$ less solar energy gains compared to the house with single glazed windows. The solar gains are, however, greater with triple vacuum glazed windows when compared to triple glazed air filled windows, this increase occurs due to the difference in the cavity gap of triple vacuum glazing i.e. $0.13 \mathrm{~mm}$ and triple air filled glazing i.e. $12 \mathrm{~mm}$. Both windows were modelled with three low emittance tin oxide coatings. The reduction in $U$ value for the triple vacuum glazed window will be more beneficial in terms of total heat load than the greater solar gains of the single glazed window.

\subsection{Winter solar energy gains analysis}

The solar energy gains on a daily basis during the winter months (Dec, Jan and Feb) were predicted. The differences in cumulative solar gain predicted were 21.7
$\mathrm{kWh}, 28.4 \mathrm{kWh}$ and $25.2 \mathrm{kWh}$ for the months of Dec, Jan and Feb when replacing single glazed windows with triple vacuum glazed windows in the solid wall detached house, as shown in in Figs. 9, 10 and 11. The maximum total solar energy gain was predicted to be $260 \mathrm{kWh}$ for the house with single glazed windows for the winter months. A decrease in total solar gains of $47.1 \mathrm{kWh}, 46.2 \mathrm{kWh}, 80.4 \mathrm{kWh}$ and $75.3 \mathrm{kWh}$ were calculated for this dwelling for the winter months for the house with double glazed air filled, double glazed argon gas filled, triple glazed air filled and triple vacuum glazed windows when compared to the house with single glazed windows. The total solar energy gain during the winter months was predicted to increase by $5.1 \mathrm{kWh}$ in the house with triple vacuum glazed windows compared to the house with triple glazed air filled windows due to the difference in glazing width and frame effects.

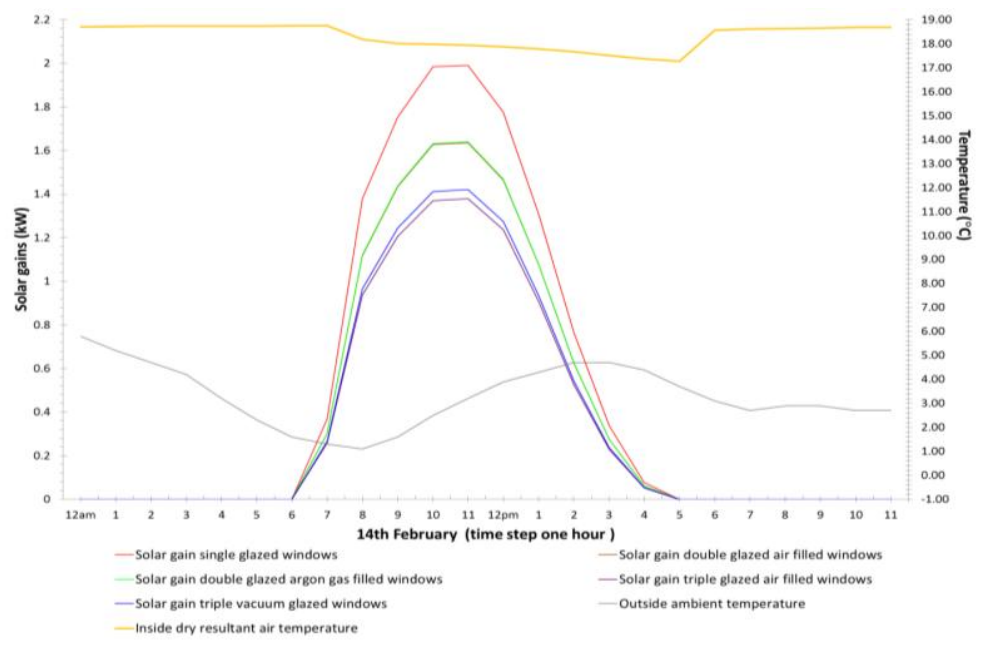

Fig. 8 Solar gain analysis for a day of high solar gain (14th February) during the winter months (Dec, Jan and Feb) 
Citation: Memon, S. (2014), Analysing the potential of retrofitting ultra-low heat loss triple vacuum glazed windows to an existing UK solid wall dwelling. Int. Journal of Renewable Energy Development, 3(3),161-174, doi: 10.14710/ijred.3.3.161-174

P a g e | 170

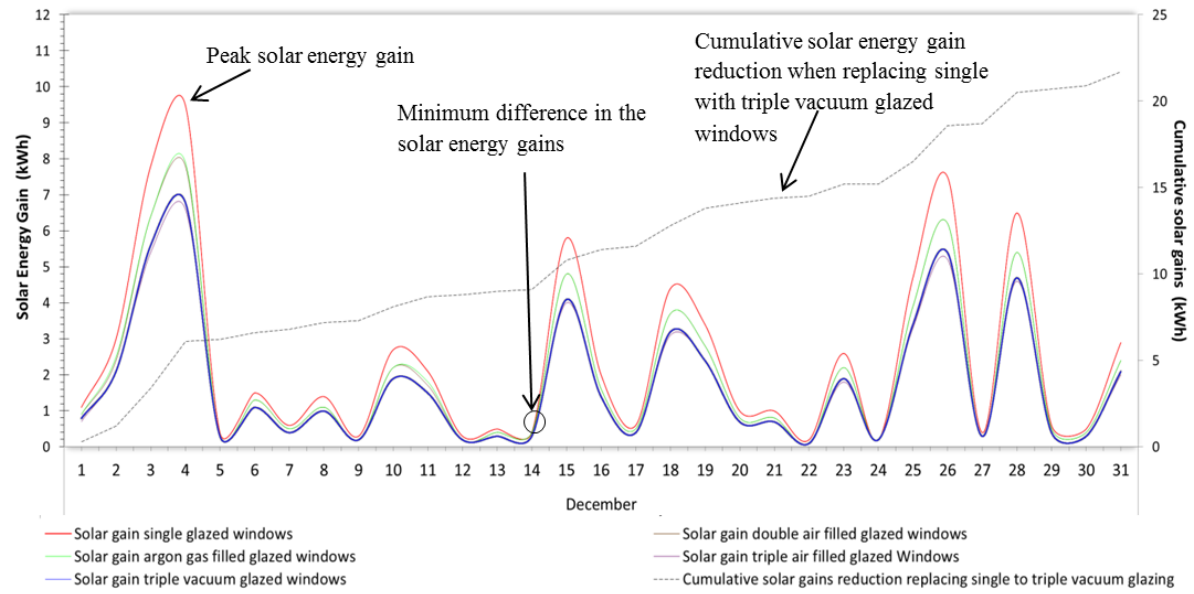

Fig. 9 Predicted solar energy gain for the month of December for the house with single, double glazed air filled, double glazed argo n gas filled, triple glazed air filled and triple vacuum glazed windows.

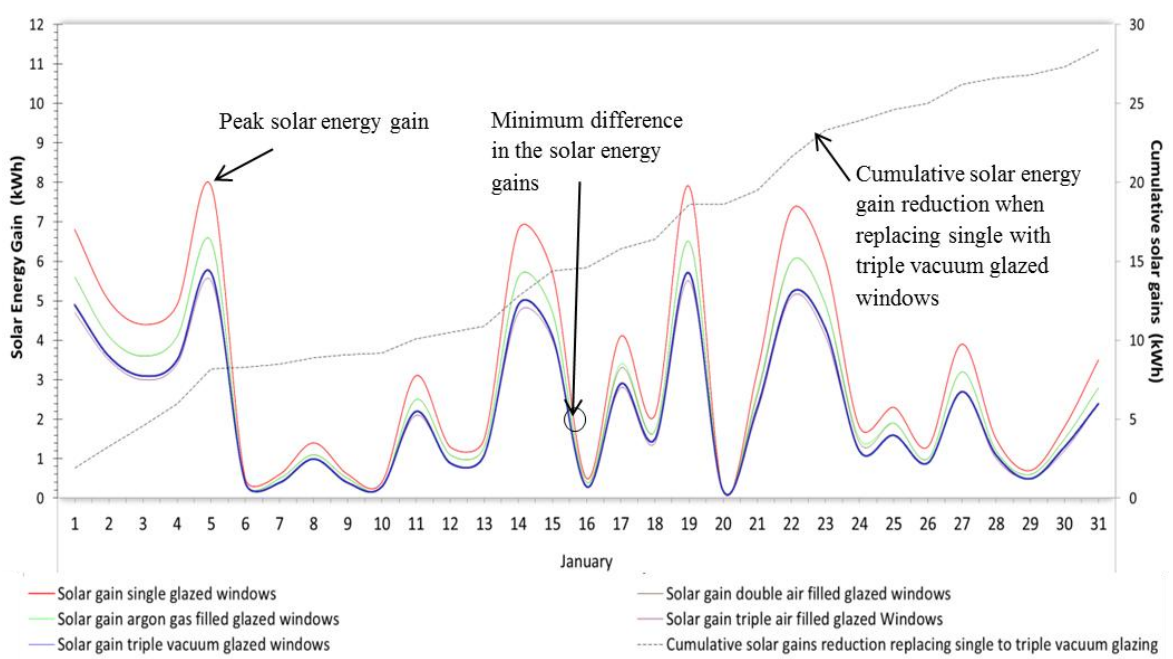

Fig. 10 Predicted solar energy gain for the month of January for the house with single, double glazed air filled double glazed, argon gas filled, triple glazed air filled and triple vacuum glazed windows.

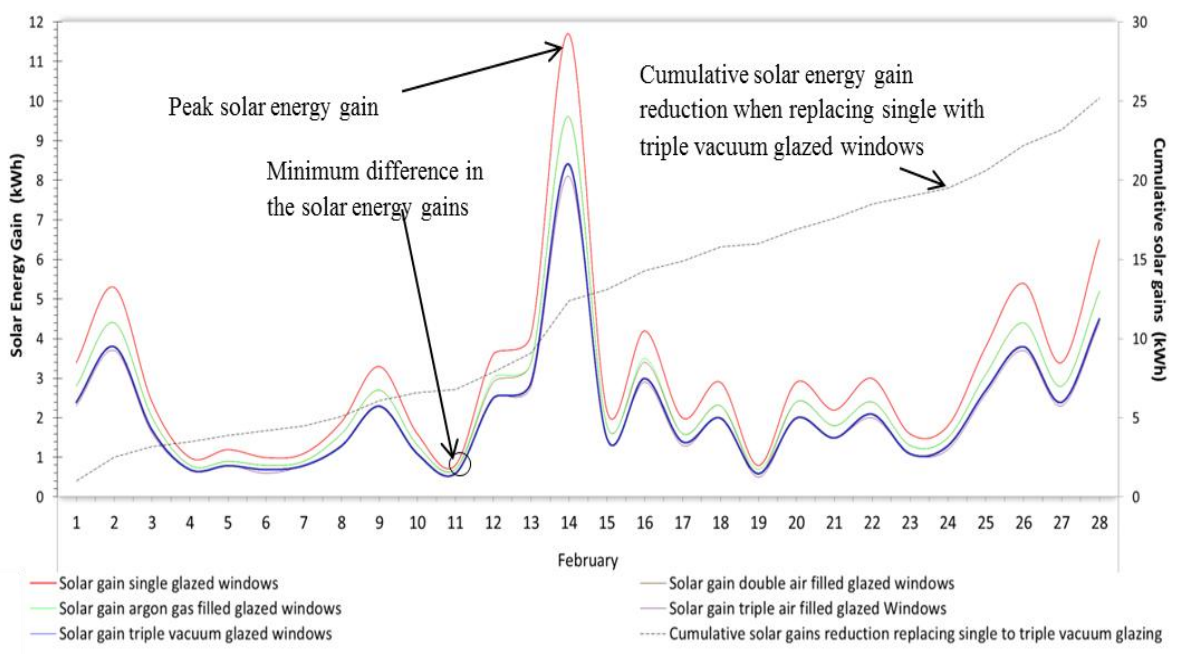

Fig. 11 Predicted solar energy gain for the month of February for the house with single, double glazed air filled, double glazed argon gas filled, triple glazed air filled and triple vacuum glazed windows. 


\subsection{The effect of changing window-to-wall area ratios on} winter heating energy requirement

Heat loss from windows is one of the key factors in the high space-heating energy requirement in the UK. Window to wall area ratio, the type of windows used, orientation of the windows and the type of frame used all influence the heat loss through the building envelope. An investigation into the effect of changing window to wall area ratio on predicted winter months space-heating energy requirements was undertaken for a single room (Bedroom 1) to compare the performance of triple vacuum glazing with single, double glazed air filled, double glazed argon gas filled and triple glazed air filled windows. In these simulations, all other elements of the detached house were not considered, with the internal walls, floor and ceiling of the room assumed to be adiabatic.

The simulations indicated that by increasing the window to wall area ratios from 5\% and 59\%, the winter months heating energy requirement increases for rooms with single, double glazed air filled, double glazed argon gas filled and triple glazed air filled windows. A decrease in the winter months heating energy requirement was however predicted for the room with a triple vacuum glazed window with increasing window to wall area ratio, as shown in Fig. 12. The simulated results show that when increasing WWR from 5\% (when the predicted heating energy was $334.9 \mathrm{kWh}$ ) to $59 \%$ (when the predicted heating energy was $209 \mathrm{kWh}$ ), the total winter months heating energy requirement decreased by $125.9 \mathrm{kWh}$, due to the lower centre-of-pane $U$ value of the triple vacuum glazed windows when compared to the $U$ value of the externally insulated solid wall. A small difference in the required heating energy was predicted for the room with double glazed air filled window when compared to double glazed argon gas filled window due to the difference in window U-values.

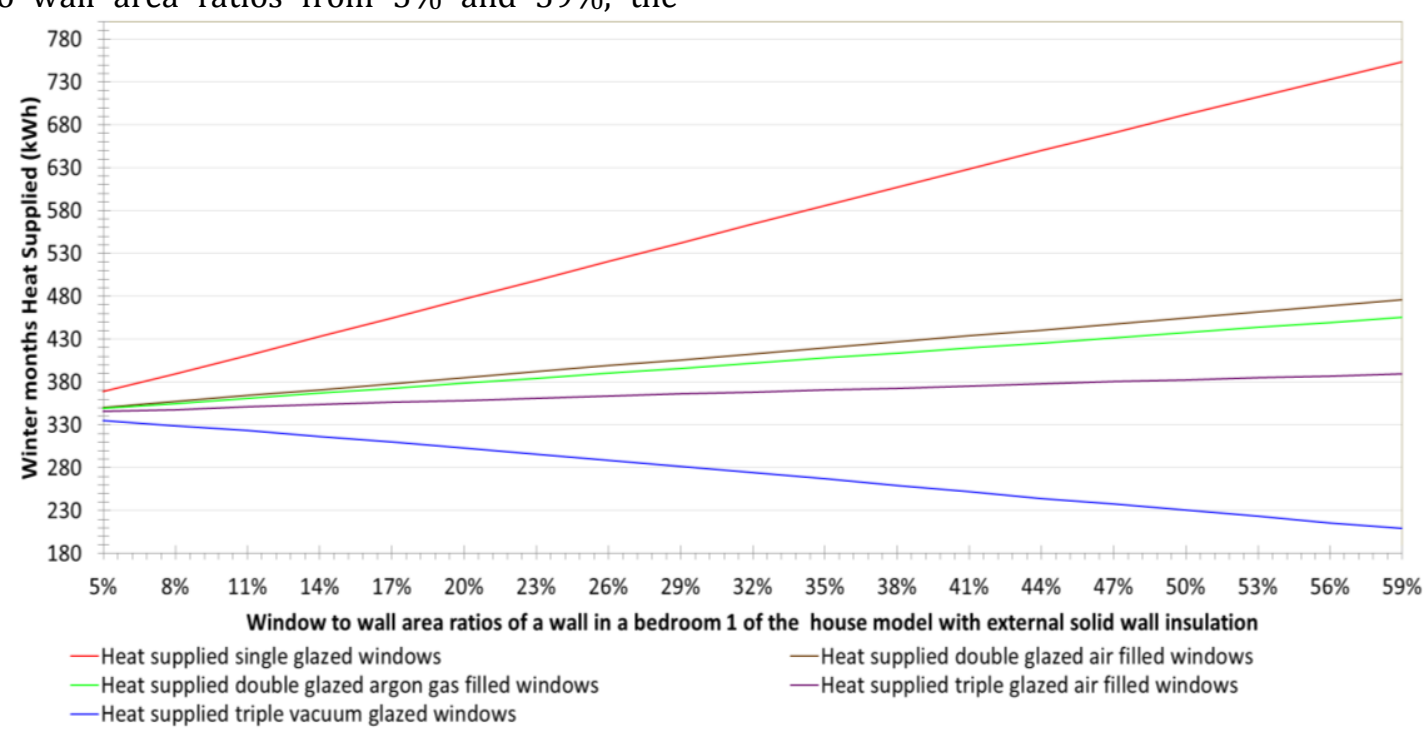

Fig. 12 The effect of changing window to wall area ratios (WWR) from $5 \%$ to $59 \%$ on the winter months heating energy requirement for a room (Bedroom 1) for single, double glazed air filled, double glazed argon gas filled, triple glazed air filled and triple vacuum glazed windows.

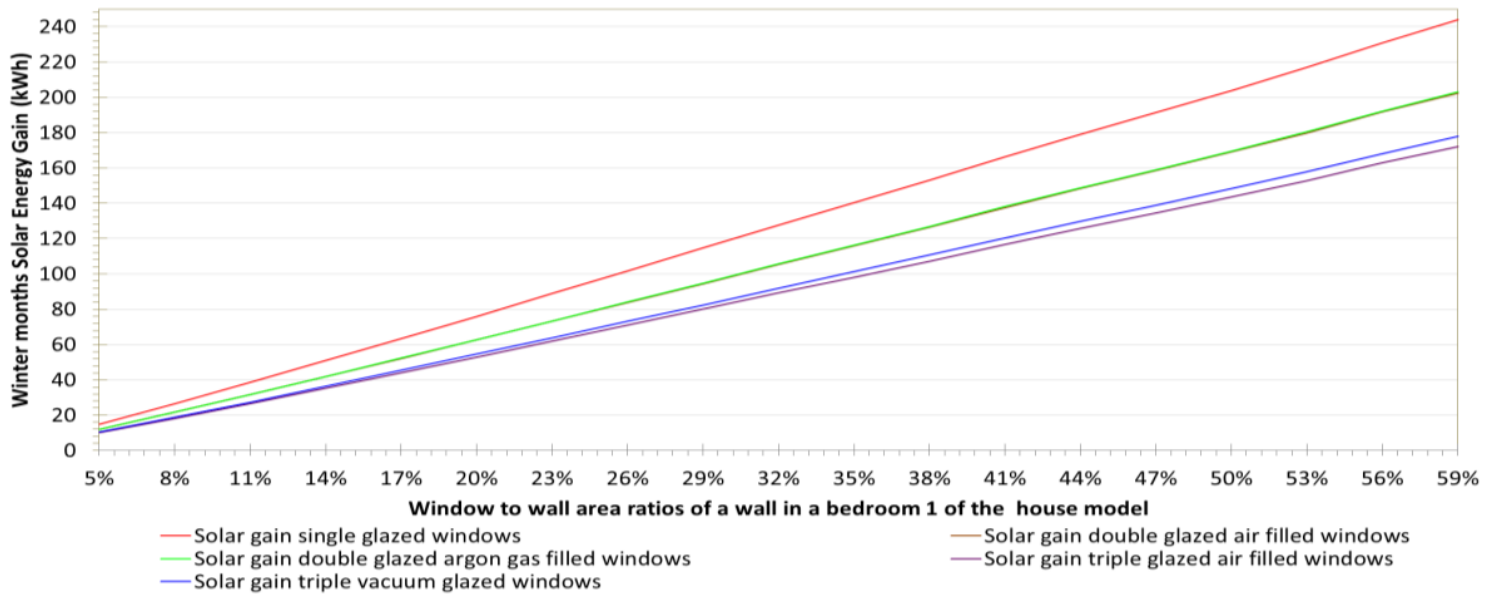

Fig. 13 The effect of changing window to wall area ratios (WWR) from $5 \%$ to $59 \%$ on the winter solar gains for wall in a Bedroom 1 for single, double glazed air filled, double glazed argon gas filled, triple glazed air filled and triple vacuum glazed windows. 


\subsection{The effect of changing window-to-wall area ratios on winter solar energy gain}

The effect of changing window to wall area ratios from $5 \%$ to $59 \%$ on the winter months heating energy requirement for a room (Bedroom 1 ) in the solid wall detached house was predicted, as shown in Fig. 13. It can be seen that solar energy gains are higher in a room with a single glazed window when compared to other window types. At WWR of 59\%, the decrease in solar energy gains compared to a room with a single glazed window were predicted to be $41.4 \mathrm{kWh}, 40.7 \mathrm{kWh}, 71.7$ $\mathrm{kWh}$ and $66.1 \mathrm{kWh}$ for double glazed air filled, double glazed argon gas filled, triple glazed air filled and triple vacuum glazed windows respectively. A small increase in solar gains i.e. $5.6 \mathrm{kWh}$ was predicted for a room with a triple vacuum glazed window compared to a triple glazed air filled window.

\subsection{Space-heating energy cost and savings analysis}

Domestic space-heat energy savings were predicted to be achieved by using triple vacuum glazed windows. Energy costs were calculated based on a standard gas tariff (initial $2680 \mathrm{kWh}$ per year costs 8.68 pence/kWh and subsequent consumption charged 3.96 pence $/ \mathrm{kWh}$ ) (British Gas 2012). Fig. 14 indicates the winter energy and cost savings of $14.58 \%$ and $£ 34.40$, respectively, for the house with triple vacuum glazed windows when compared to the house with single glazed windows. The simulated results show little difference in energy savings, $7.35 \%$, and cost savings, $£ 10.45$, for the house with triple air filled glazed windows compared to triple vacuum glazed windows for the winter months.

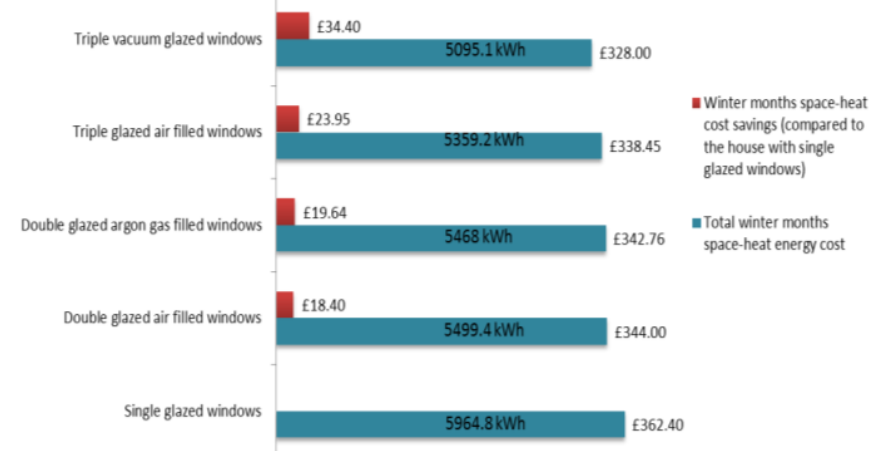

Fig. 14 Predicted winter heating energy and cost savings for the modelled house with single, double glazed air filled, double glazed argon gas filled, triple glazed air filled and triple vacuum glazed windows.

It is, however, not possible to compare the production cost of triple vacuum glazing with triple air filled glazing, this is because triple vacuum glazing is not yet available at the production level. Fabrication cost of triple vacuum glazing is dependent on the type of edge sealing materials used, the details of the novel cost effective materials design and fabrication techniques are reported in Memon (2013) which indicate the saving of frame material (due to its thinness) and the use of cost-effective glass edge sealing materials which will reduce the overall cost of triple vacuum glazing compared to the conventional production cost of triple air filled glazing. Energy and cost savings for the winter months of $7.8 \%, 8.33 \%$ and $10.15 \%$ and $€ 18.40, £ 19.64$ and $£ 23.95$ respectively were predicted for the house with double glazed air filled, double glazed argon gas filled and triple glazed air filled windows when compared to the house with single glazed windows. The required annual heating energy was simulated as shown in Fig. 15. It was predicted that the required annual heating energy and cost savings of $15.31 \%$ and $€ 73.70$, respectively, could be achieved by replacing single glazed windows with triple vacuum glazed windows. Annual energy and cost savings of $7.94 \%, 8.62 \%$ and $9.67 \%$ and $€ 38.25, £ 41.49$ and $£ 46.54$, respectively, were calculated based on the required annual heating energy in the house with double glazed air filled, double glazed argon gas filled and triple glazed air filled windows when compared to the house with single glazed windows. The predictions show that an annual heating energy and cost savings of $6.24 \%$ and $£ 27.16$, respectively, can be achieved in the house with triple vacuum glazed windows compared to triple glazed air filled windows.

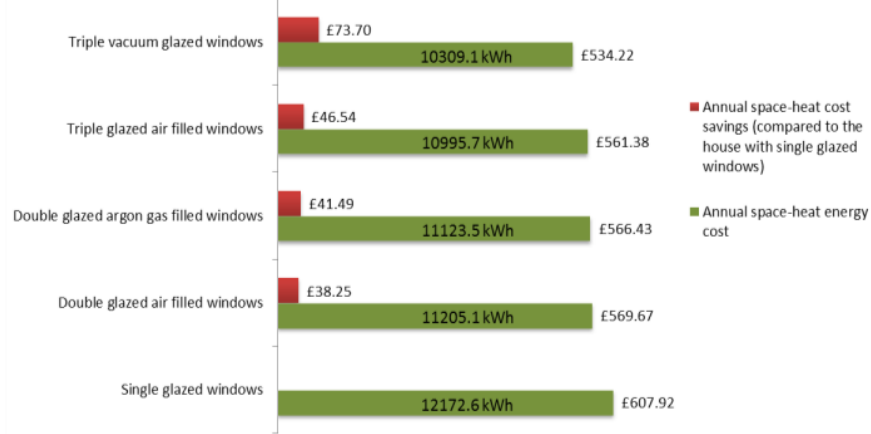

Fig. 15 Predicted annual heating energy and cost savings analysis for the modelled house with single, double glazed air filled, double glazed argon gas filled, triple glazed air filled and triple vacuum glazed windows.

\section{Conclusion}

An externally insulated solid wall house model was developed to simulate heat load and solar gain when using single glazed, double glazed air filled, double glazed argon gas filled, triple glazed air filled and triple vacuum glazed windows. Winter heat loads were analysed and it was predicted that the heat load can be reduced significantly by using triple vacuum glazed windows. A decrease in solar gains for the winter months was predicted in the house model with triple vacuum glazed windows compared to single glazed 
windows. Predictions for the annual and winter month's costs of space-heating energy and potential financial savings resulting from replacing single glazed windows by triple vacuum glazed windows were made. It was also shown that for triple vacuum glazed window it is possible to significantly increase window to wall area ratios without an increase in room heat load, for triple air filled glazed window a little increase in room heat load was predicted. The future work recommendation is to install triple vacuum glazing to a solid wall dwelling and monitor the space-heating load and solar energy gains for the winter and annual months; which could then be compared to the model predictions made in this research paper.

\section{Acknowledgement}

Work supported by Engineering and Physical Sciences Research Council (EPSRC) of the UK (EP/G000387/1) as a contribution to the Work Package 3.4 of the CALEBRE (Consumer-Appealing Low Energy Technologies for Building Retrofitting) project. The author thanks P. C. Eames for his supervision of conducting this research during the doctoral studies at Loughborough University, UK. Permission to reproduce equations from British Standards is granted by BSI.

\section{References}

ASHRAE (1989) ASHRAE Guideline 62-1989: Ventilation for acceptable indoor air quality. American Society of Heating, Refrigerating and Air-Conditioning Engineers.

Banfill, P., Simpson, S., Haines, V. \& Mallaband, B. (2011) Energy-led retrofitting of solid wall dwellings: technical and user perspectives on airtightness. Journal of Structural Survey 30: 267-279.

Baker, N. \& Steemers, K (1996) LT Method 3.0-a strategic energydesign tool for Southern Europe. Journal of Energy and Buildings 23: 251-256.

Birch, A (2010) BRE's Victorian terrace retrofit project, Building design online. Available via http://www.bdonline.co.uk/bre\%E2\%80\%99s-victorian-terraceretrofit-project/5000095.article. Accessed 15 Dec 2012.

Boardman, B., Darby, S., Philip, G., Hinnells, M., Jardine, C.N., Palmer, J. \& Sinden, G (2005) 40\% House. Environmental Change Institute, University of Oxford.

BRE (2012) The Government's Standard Assessment Procedure for Energy rating of Dwellings,Garston: Building Research Establishment. Available via www.bre.co.uk/sap2005. Accessed 25 Oct 2012.

BS (2007a) BS EN ISO 6946: Building components and building elements-Thermal resistance and thermal transmittanceCalculation method. British Standard.

BS (2007b) BS EN 13779: Ventilation for non-residential buildingsPerformance requirements for ventilation and room-conditioning systems. British Standard.

BS (2006) BS En ISO 10077-1: Thermal performance of windows, doors and shutters-calculation of thermal transmittance Part 1 General. British Standard.

BS (2003) BS En ISO 10077-2: Thermal performance of windows, doors and shutters-calculation of thermal transmittance Part 2 Numerical method for frames. British Standard.

BS (1998) BS EN 673: Glass in building-Determination of thermal transmittance (Uvalue)-Calculation method. British Standard.

British Gas (2012). Energy tariffs standard. Available via http://www.britishgas.co.uk/products-and-services/energy/ourtariffs/standard.html\#PriceMapFlash. Accessed on 16 Dec 2012.
Crawley, D. B., Hand, J. W., Kummert, M. \& Griffith, B. T (2008) Contrasting the capabilities of building energy performance simulation programs. Building and Environment, 43 (4): 661-673.

CIBSE (2012) Guide F: Energy efficiency in buildings (3rd eds), The Chartered Institution of Building Services Engineers, London.

CIBSE (2006) Guide A: Environmental Design ( $7^{\text {th }}$ eds), The Chartered Institution of Building Services Engineers, London.

CIBSE (1997) Guide AM10: Natural Ventilation in Non-domestic Buildings. CIBSE application manual, The Chartered Institution of Building Services Engineers, London.

Energy Savings Trust (2006) CE184: Practical Refurbishment of SolidWalled Houses, Energy Savings Trust, 20.

Guillery, A., Donald, D. \& Kendall (2004) The small house in eighteenthcentury London: a social and architectural history, New Haven: Yale UniversityPress.

Holt, T \& Schalom, G (2012) Homes behaving badly-The HOBBS report 2012. Available via http://aecb.net/news/wpcontent/uploads/2012/04/HOBBs-Final-Small-Indexed.pdf. Accessed 13 Dec. 2012.

IES (2012) Integrated Environmental Solutions VE Dynamic Thermal Modelling Software version 6.4.0.10.

IES-ASHRAE (2012) Integrated Environment Solutions VE ASHRAE weather database version 4.0, APLocate User Guide. Available via www.iesve.com/content/downloadasset_2878. Accessed 5 Aug 2012.

IES-ApacheSim (2012) ApacheSim Calculation Methods-User guide. Available via <http://www.iesve.com/downloads/help/Thermal/Reference/A pacheSimCalculationMethods.pdf. Accessed 2 Aug 2012.

IES-Part L2 (2006) Building Regulations IES-VE-SBEM User Guide. Available via www.iesve.com/content/downloadasset_2908. Accessed 23 Nov 2012.

Jenkins, D. P (2010) The value of retrofitting carbon-saving measures into fuel poor social housing. Journal of Energy Policy 38: 832-839.

Jenkins, D (2008) Energy Modelling In Traditional Scottish Houses (EMITSH). In: The technical report of historic Scotland, Technical Conservation Group. Available via http://www.historicscotland.gov.uk/energy-modelling-scottish-houses.pdf. Accessed 10 Dec. 2012.

Jelle, B. P., Hynd, A., Gustavsen, A., Arasteh, D., Goudey, H. \& Hart, R (2012) Fenestration of today and tomorrow: A state-of-the-art review and future research opportunities. Journal of Solar Energy Materials \& Solar Cells 96: 1-28.

Loveday, D., Vadodaria, K, Haines, V., Hewitt, N., Hyde, T., Griffiths, P., Critoph, B., Eames, P., Banfill, P., Gillot, M., Darlington, R., Hall, M. \& Tsang E (2011). Refurbishing the UK's 'hard to treat' dwelling stock: Understanding challenges and constraints, paper presented at the CIBSE Technical Symposium, De Montford University, Leicester, 13: 1-13.

Lofthouse, P (2012) The development of English semi-detached dwellings during the nineteenth century, papers from the institute of Archaeology PIA, London, 22: 83-98.

London Development Agency (2009) London housing design guidedraft for consultation. Available via http://www.lifetimehomes.org.uk/data/files/Reports/londonhou singdesignguidepdf1.pdf. Accessed $10 \mathrm{Feb} 2013$.

Mardaljevic, J., Heschong, L. \& Lee, E (2009) Daylight metrics and energy savings. Journal of Lighting Research and Technology, 41: 261-83.

Memon, S. (2013) Design, Fabrication and Performance Analysis of Vacuum Glazing Units Fabricated with Low and High Temperature Hermetic Glass Edge Sealing Materials. PhD Thesis. Loughborough University, UK.

Moorhouse, J., Littlewood, J. (2012) The Low-carbon retrofit of a UK conservation area terrace: introducing a pattern book of energysaving details. In: Proceedings of the $3^{\text {rd }}$ International conference on Sustainability in Energy and Buildings (SEB 11), Springer, 12: 297-305.

Mudarri, D.H (2010) Building Codes and Indoor Air Quality. US Environmental Protection Agency-Office of radiation and Indoor Air Indoor Environments Division. Available via www.epa.gov/iaq/pdfs/building_codes_and_iaq.pdf. Accessed 23 Nov 2012. 
Ochoa, C. E, Aries, M.B.C., Van-Leonen, E. J. \& Hensen, J.L.M (2012). Considerations on design optimization criteria for windows providing low energy consumption and high visual comfort. Journal of Applied Energy 95: 238-245.

Papakostas, K.T. \& Sotiropoulos, B.A (1997) Occupational and energy behaviour patterns in Greek residences. Journal of Energy and Buildings 26: 207-213.

Peacock, A., Eames, P.C., Singh, H., Berry, T.J., Banfill, P.F., Turan, S Jenkins, D., Ahadzi, M., Bowles, G., Kane, D. \& Newborough, M (2007). Reducing $\mathrm{CO}_{2}$ emissions through refurbishment of UK housing, ECEEE Summer Study. Saving Energy-Just do It. Panel 5, Energy Efficient Buildings, 5-201.
Porritt, S.M., Shao, L., Cropper, P.C. \& Goodier, C.I. (2010) Occupancy patterns and their effect on interventions to reduce overheating in dwellings during heat waves, In: Proceedings of Conference: Adapting to Change: New Thinking on Comfort, London: Network for Comfort and Energy Use in Buildings.

Smeaton, A. C. (1867) The builder's pocket companion; containing the elements of building, surveying and architecture. Philadelphis, Baird $\mathrm{H}$.

Vadodaria, K., Loveday, D., Victoria, H., Mitchall, V., Mallaband, B., Bayer, S.H (2010) UK Solid-wall dwellings- thermal comfort, energy efficiency refurbishment and the user perspective-some preliminary analyses from the CALEBRE project. In: Proceedings of Conference: Adapting to Change: New Thinking on Comfort, London: Network for Comfort and Energy Use in Buildings. 